\title{
Critical Discourse Analysis in Teaching Reading
}

\author{
Elok Putri Nimasari \\ elokputrinimasari@gmail.com \\ Muhammadiyah University of Ponorogo \\ Jl. Budi Utomo No. 10, Ponorogo, Jawa Timur, Indonesia
}

Received: June 29, 2016; Accepted: September 3, 2016; Published: September 27, 2016

\begin{abstract}
In Indonesian context, it is mostly found that reading material and its exercises examine of what have been explicitly discussed. Critical thinking is less introduced within reading texts and somehow it makes the students less understandable to know what is exactly meant by the author. However, when the students are able to think critically, they will also be able to connect between ideas and to solve the problems with logical reasons. From this reason, it is clearly seen that critical thinking should be introduced, for instance, through reading texts and its exercises. This article aims to present one idea that can be used to raise critical thinking by implementing a critical discourse analysis. Therefore, the relevant literature of teaching reading, CDA, the description of how the material is integrated with CDA and the teaching sequence will be described. It is expected that this article will have deeper insight and significant implication for some educational parties such as teachers and lecturers.
\end{abstract}

Keywords: teaching reading, university students, critical discourse analysis, teaching sequence

How to cite this paper: Nimasari, E. P. (2016). Critical Discourse Analysis in Teaching Reading. Journal on English as a Foreign Language, 6(2), 119-130.

Reading cannot be separated with other English skills. The students will not be completely successful in acquiring English without having a good understanding of the text they are interacting with. According to Hartmann and Stork cited in Zainuddin (2015), reading is the ability to get information from a series of graphic signs which can be a meaningful speech done by either silent 
reading or reading aloud. However, each text has different characteristics. As Brown (2001, p. 186) said that each type or genre of written text has its own set of governing rules and conventions. A reader must be able to anticipate those conventions in order to process meaning efficiently. With an extraordinary number of genres present in any literate culture, the reader's ability to process texts must be very sophisticated.

There are three levels of reading comprehensions (Rodli, 2015). Those are literal comprehension, inferential comprehension, critical reading, and creative reading. Literal reading comprehension relates to finding information stated in the text while inferential reading comprehension is about connecting ideas between one to another paragraph in a text. Different from those levels, critical and creative reading include one's critical thinking and awareness towards implicit ideas beyond the text. In the university level, students are prepared to be ready for real-world demands. Reading skill can give university students such reference and literacy to solve problems (Rahayu \& Februariyanti, 2015). Prerequisite abilities for university students involve critical thinking skill, creative skills, and analysis skills (Ghazivakili et al., 2014).

One of the current issues in ELT for reading class particularly in Indonesian context is critical thinking in reading. Findings of previous studies have indicated that university students are less motivated to read their textbooks. Thus, their critical thinking and analysis skills also less developed (Junining, n.d.; Sunggingwati, 2013; Masduqi, 2014; Ubaidillah, n.d.). Having unequal points of view sometimes is rarely. When critical discourse analysis is included in teaching reading, students will have awareness of the existence of exploitative social relations through the deconstruction of language use (Ali, 2011).

Further, some studies have reviewed the significant improvement of integrating CDA in teaching reading. A study revealed that students' critical language awareness and their motivation increased after having some CDA's techniques in their reading course (Rahimi, 2010). Another research, CDA can help the students to find hidden message and to relate what goes behind the text (Amari, 2015). For giving more significant implication in the implementation of CDA particularly for reading class in EFL context, this article presents present one idea that can be used to raise critical thinking by implementing a critical discourse analysis. Relevant literature of teaching reading, CDA, the description of how the material is integrated with CDA and the teaching sequence will be described. 


\section{TEACHING READING}

Reading is included into receptive skill where the students have to understand the meaning from the text (Ullah \& Fatema, 2013). This skill somehow seems less active than the other productive skills. However, having a good spoken language will be meaningless if the students have difficulties in understanding the text. The students have to be given an appropriate material of reading to achieve reading's purposes. Therefore, the material given should cover the skills required for reading.

According to Brown (2001, p. 187-188), there are some micro and macro skills. Micro skills which are called as sub-skills refer to understanding the parts of linguistic features such as grammatical structure, cohesive devices, meaning, word order, spelling, writing, and their significance. Meanwhile, macro skills relate to the comprehension the ideas within the text, among paragraphs such as main idea, supporting ideas, detail information both literal and implied, context, communicative function, and reading strategies.

Basically, there are two processing techniques in interpreting the text for reading, top-down and bottom-up technique (Harmer, 2007; Gurses \& Adiguzel, 2013). Top-down processing leads the readers to get a general view of the text. This technique will be grateful for those who have schemata related to the text they are going to interpret. On the other hand, bottom-up processing starts from individual words, phrases, or cohesive devices, and then achieves understanding by stringing those detailed elements to build up a whole.

\section{CRITICAL DISCOURSE ANALYSIS}

Critical discourse analysis focuses on revealing explicit and implicit socio-political domination which includes social change, power abuse, ideological imposition, and social injustice by critically analyzing language as social action Wodak (2009). In critical discourse perspective, the language is supposed to be a vehicle to uncover hidden assumption or ideology of the user. Further, social and linguistic aspects can be integrated by using CDA (Samadikhah \& Shahrokhi, 2015). Since CDA has such benefits, integrating CDA within the text for reading class is expected to raise students' critical thinking and awareness toward written forms they read. In addition, critical discourse brings students to get the implied information.

There are several approaches to critical discourse analysis with different exponents and frameworks. The model of analysis proposed by Wodak (2009) in 'The Discourse-Historical Approach' covers three steps. Those three steps are describing the content of specific topic of a discourse, investigating discursive and argumentative strategies used, and analyzing the realizations of particular written linguistic meanings in a specific context. Then, five following questions 
are proposed to give such a guidance in describing those three steps. It can be used as the principles to describe the discourse. Those are:

1. How names are linguistically constructed and to whom do they refer?

2. How those discursive actors are constructed in terms of personality, character, and appearance?

3. What specific arguments and argumentative strategies are those people presented? Are they described exclusively or inclusively?

4. From what perspective are the labeling, description and argumentation made?

5. Are the messages delivered clearly, intensively or made in disguise?

\section{Critical Discourse Analysis Description within the Text to Teach Reading}

Critical discourse analysis (CDA) identifies and explains implicit or explicit relation and the association between language, power, and ideology (Wodak, 2009). Since reading somehow seems less active than the other productive skills, it is necessary to improve this skill through suitable approach. For this reason, CDA is considered to be an appropriate discourse perspective in analyzing and teaching reading, especially for argumentative text.

There are many micro and macro skills of reading. In this occasion, there are only several micro and macro skills which are taken as the required skills of teaching reading incorporated with CDA. For sub-skills, recognizing grammatical word class, systems, patterns, elliptical forms, cohesive devices and their role in determining the relationship between and among clauses are described. For macro skills, recognizing the rhetorical forms of written discourse, their significance for interpretation, and the communicative functions of written texts are described.

The following section is an argumentative text by Mahatma Gandhi (Mandal, 2014). This speech is analyzed using CDA with the model of analysis proposed by Wodak (2009) and in the argumentative discursive strategy.

\section{The Quit India speech by Mahatma Gandhi on August 8th, 1942}

Before you discuss the resolution, let me place before you one or two things, I want you to understand two things very clearly and to consider them from the same point of view from which I am placing them before you. I ask you to consider it from my point of view, because if you approve of it, you will be enjoined to carry out all I say. It will be a great responsibility. There are people who ask me whether I am the same man that I was in 1920, or whether there has been any change in me. You are right in asking that question.

Let me; however, hasten to assure that I am the same Gandhi as I was in 1920. I have not changed in any fundamental respect. I attach the same importance to non- 
violence that I did then. If at all, my emphasis on it has grown stronger. There is no real contradiction between the present resolution and my previous writings and utterances.

Occasions like the present do not occur in everybody's and but rarely in anybody's life. I want you to know and feel that there is nothing but purest Ahimsa1 in all that I am saying and doing today. The draft resolution of the Working Committee is based on Ahimsa; the contemplated struggle similarly has its roots in Ahimsa. If, therefore, there is any among you who has lost faith in Ahimsa or is wearied of it, let him not vote for this resolution.

Let me explain my position clearly. God has vouchsafed to me a priceless gift in the weapon of Ahimsa. I and my Ahimsa are on our trail today. If in the present crisis, when the earth is being scorched by the flames of Himsa2 and crying for deliverance, I failed to make use of the God given talent, God will not forgive me and I shall be judged un-wrongly of the great gift. I must act now. I may not hesitate and merely look on, when Russia and China are threatened.

Ours is not a drive for power, but purely a non-violent fight for India's independence. In a violent struggle, a successful general has been often known to effect a military coup and to set up a dictatorship. But under the Congress scheme of things, essentially non-violent as it is, there can be no room for dictatorship. A non-violent soldier of freedom will covet nothing for himself; he fights only for the freedom of his country. The Congress is unconcerned as to who will rule when freedom is attained. The power, when it comes, will belong to the people of India, and it will be for them to decide to whom it placed in the entrusted. Maybe that the reins will be placed in the hands of the Parsis, for instance as I would love to see happen or they may be handed to some others whose names are not heard in the Congress today. It will not be for you then to object saying, "This community is microscopic. That party did not play its due part in the freedom's struggle; why should it have all the power?" Ever since its inception the Congress has kept itself meticulously free of the communal taint. It has thought always in terms of the whole nation and has acted accordingly. . .

I know how imperfect our Ahimsa is and how far away we are still from the ideal, but in Ahimsa there is no final failure or defeat. I have faith, therefore, that if in spite of our shortcomings, the big thing does happen, it will be because God wanted to help us by crowning with success our silent, unremitting Sadhana1 for the last twentytwo years.

I believe that in the history of the world, there has not been a more genuinely democratic struggle for freedom than ours. I read Carlyle's French Resolution while I was in prison, and Pandit Jawaharlal has told me something about the Russian revolution. But it is my conviction that inasmuch as these struggles were fought with the weapon of violence they failed to realize the democratic ideal. In the democracy which I have envisaged, a democracy established by non-violence, there will be equal freedom for all. Everybody will be his own master. It is to join a struggle for such 
democracy that I invite you today. Once you realize this you will forget the differences between the Hindus and Muslims, and think of yourselves as Indians only, engaged in the common struggle for independence.

Then, there is the question of your attitude towards the British. I have noticed that there is hatred towards the British among the people. The people say they are disgusted with their behavior. The people make no distinction between British imperialism and the British people. To them, the two are one. This hatred would even make them welcome the Japanese. It is most dangerous. It means that they will exchange one slavery for another. We must get rid of this feeling. Our quarrel is not with the British people, we fight their imperialism. The proposal for the withdrawal of British power did not come out of anger. It came to enable India to play its due part at the present critical juncture. It is not a happy position for a big country like India to be merely helping with money and material obtained willy-nilly from her while the United Nations are conducting the war. We cannot evoke the true spirit of sacrifice and valour, so long as we are not free. I know the British Government will not be able to withhold freedom from us when we have made enough self-sacrifice. We must, therefore, purge ourselves of hatred. Speaking for myself, I can say that I have never felt any hatred. As a matter of fact, I feel myself be a greater friend of the British now than ever before. One reason is that they are today in distress. My very friendship, therefore, demands that I should try to save them from their mistakes. As I view the situation, they are on the brink of an abyss. It, therefore, becomes my duty to warn them of their danger even though it may, for the time being, anger them to the point of cutting off the friendly hand that is stretched out to help them. People may laugh, nevertheless, that is my claim. At a time when I may have to launch the biggest struggle of my life, I may not harbor hatred against anybody.

(The speech is taken a half. It can be adaptable to students' level)

The following description will guide the teacher how the material should be used according to Wodak and Meyer perspective. Practically, the description may have wider and deeper explanation. The description below is only the example of how the text is analyzed using CDA and linked to cover the macro and micro skills of reading. Moreover, the descriptions highlight argumentative discursive strategy.

Related to the first description, how names are linguistically constructed and to whom do they refer to, Mahatma Gandhi was Indian. He was the leader of Indian independence movement in British-ruled India. Based on the speech above, it can be seen that he led India to independence through the non-violent fight. He promoted freedom across the world. Gandhi was known as the inspired one for civil rights movement. He attempted to practice non-violence and truth in all situations. It can be seen in the argument below: 
.....Let me; however, hasten to assure that I am the same Gandhi as I was in 1920. I have not changed in any fundamental respect. I attach the same importance to non-violence that I did then. If at all, my emphasis on it has grown stronger. There is no real contradiction between the present resolution and my previous writings and utterances.....

[Paragraph 2]

The second description will be described. It is about Gandhi's personality, character, and appearance. Let us see his argument below.

...... Occasions like the present do not occur in everybody's and but rarely in anybody's life. I want you to know and feel that there is nothing but purest Ahimsa1 in all that I am saying and doing today. The draft resolution of the Working Committee is based on Ahimsa; the contemplated struggle similarly has its roots in Ahimsa. If, therefore, there is any among you who has lost faith in Ahimsa or is wearied of it, let him not vote for this resolution.

Let me explain my position clearly. God has vouchsafed to me a priceless gift in the weapon of Ahimsa. I and my Ahimsa are on our trail today. If in the present crisis, when the earth is being scorched by the flames of Himsa2 and crying for deliverance, I failed to make use of the God given talent, God will not forgive me and I shall be judged un-wrongly of the great gift. I must act now. I may not hesitate and merely look on, when Russia and China are threatened.....

[Paragraph 3 and 4]

It can be seen that Gandhi was a religious man. He born and raised in a Hindu caste family. His belief belonged to Ahimsa. Ahimsa means nonviolence. He did not like war. He believed that through Ahimsa, people would be free from war. He felt that he had to do something for a change. He wanted to unite all people to save the world from conflicts. Based on his belief, Gandhi's appearance looked like other religious Hindu-Indian. He wore the traditional Indian dhoti and shawl.

The third description relates to specific arguments and argumentative strategies that Gandhi presented. The title of the speech has described the argumentative strategies. He presented his speech exclusively. The Quit India was proposed for Indian people. He tried to unify all differences in the case of non-violence struggle for Indian independence. It can be seen through this following speech. 
.....I believe that in the history of the world, there has not been a more genuinely democratic struggle for freedom than ours. I read Carlyle's French Resolution while I was in prison, and Pandit Jawaharlal has told me something about the Russian revolution. But it is my conviction that inasmuch as these struggles were fought with the weapon of violence they failed to realize the democratic ideal. In the democracy which I have envisaged, a democracy established by non-violence, there will be equal freedom for all. Everybody will be his own master. It is to join a struggle for such democracy that I invite you today. Once you realize this you will forget the differences between the Hindus and Muslims, and think of yourselves as Indians only, engaged in the common struggle for independence...

[Paragraph 7]

The fourth description comes to the perspective of the labeling, description, and argumentation. The labeling, description, and argumentation of Mahatma Gandhi speech were made from argumentative strategy. It can be seen that Gandhi used I, We, Ours, I invite you, etc. He gave a speech for against war. He tried to unite people in all differences for Indian independence purpose.

The last description leads to how the message delivered. Based on the speech above, there are some repetitions on how Gandi emphasized to assure Indian people that Ahimsa was the best way to get independence. He delivered the message and the argument clearly so that people would unify for against war.

\section{TEACHING SEQUENCE}

Having description analysis based on Wodak and Meyer perspectives, thus it links to the micro and macro skills of reading. Those CDA descriptions have covered macro skills. The rhetorical forms of written discourse have been described that it is included as argumentative text and the interpretation have been represented in line with Wodak's (2009) perspectives. Moreover, related to recognizing the communicative functions of written texts, Gandhi's speech purposed to give support, spirit, and non-violent fight against war.

In case of micro skills which are identified by grammatical word class (noun, pronoun, verb, adverb, etc.), systems (tenses, agreement, singular and plural forms), patterns (subject-verb-object), elliptical forms, cohesive devices, and their role in determining the relationship between and among clauses, the text of Gandhi's speech is so beneficial since it is an authentic material. Students can experience a real world context through authentic material although it may have different from their own context and culture (Coppens, Rico, \& Agudo, 2013; Thomas, 2014; Abdelhafez \& Abdallah, 2015). Students can be asked to 
analyze those linguistics features. For instance, in delivering a speech, the speaker uses the present tense. In analyzing speech, the reader uses past tense. Further analyses can be developed according to micro skills. The teacher can also show how the structures are organized in the text and their role in signaling the relationship between and among clauses. Therefore, micro skills can be covered.

The process of comprehending reading above starts from general view. It begins by describing the speaker, its characteristics, personality, detail arguments, and how the message delivered. Then, those set to the simple elements, grammatical form, and its role. From this process, it can be seen that teaching sequence applies top-down reading process. Detail teaching sequence of reading used top-down technique reading process and integrated with CDA model proposed by Wodak and Meyer will be described below.

Table1. Teaching Sequence

\begin{tabular}{ll}
\hline Level & Advanced Learner (University level) \\
\hline Skill & Reading \\
\hline Text Type & Argumentative Text (Speech) \\
\hline Title & The Quit India by Mahatma Gandhi (August $8^{\text {th }}$ 1942) \\
\hline Time & 1 meeting \\
Allocation & \\
\hline
\end{tabular}

Aims Students are able to:

a. Recognise grammatical word classes (nouns, verb etc.), systems (e.g. tense, agreement, pluralisation), patterns, rules, and elliptical forms.

b. Recognize cohesive devices in written discourse and their role in signaling the relationship between and among clauses.

c. Recognize the rhetorical forms of written discourse and their significance for interpretation.

d. Recognize the communicative functions of written texts, according to form and purpose.

(Skill a and b are micro skills, skill c and d are macro skills)

Sources - Mahatma Gandhi speech text

- Video of Gandhi's speech or if there is no video, the teacher can show some pictures of Mahatma Gandhi

Procedures

Pre-reading activities

1. Activating students' schemata by playing the video of Gandhi's speech or Gandhi's pictures.

Journal on English as a Foreign Language, 6(2), 119-130

Copyright (C) 2016 by JEFL, p-ISSN 2088-1657; e-ISSN 2502-6615 
2. Introducing some information of Mahatma Gandhi and the students are going to do.

While reading activities

1. Grouping the students into five members a group by Numbered Head together.

2. Distributing the text to the students.

3. Having each member to read it silently.

4. Member number 1 is grouped together to discuss their parts, and so are member number 2,3 , and 4 .

5. Having each member to discuss based on what they have to interpret. In this case, five questions to analyze the text proposed by Wodak and Meyer are used. The first question is for number 1 , and so on.

6. Asking each number to get back to their initial groups, and letting them present their own analyses, so each member of a group will understand the whole analyses.

7. Giving worksheets to all groups.

8. Asking all groups to analyze the grammatical rules by breaking the paragraph into sentences, phrases, and words.

9. Asking all groups to identify discourse in signaling the relationship between and among clauses.

10. Finally, asking each group to present their findings so that the teacher and other groups can give feedback and get benefits from the presentation.

Post-reading activities

1. Comparing Mahatma Gandhi with some figures from Indonesia.

2. Asking students to give opinions related to some Indonesian figures which have the same occasion with Mahatma Gandhi.

3. Concluding what the class has done.

\section{CONCLUSION}

Based on the discussion above there are two main parts of the descriptions. Firstly, the description how the material should be used according to CDA model proposed by Wodak (2009) can be used to help the teacher in teaching reading using the argumentative text by Gandhi and this model can cover both micro and macro skills of reading. Secondly, the description of teaching sequence is drawn to guide the teacher in implementing CDA for reading class.

Those descriptions can be implemented in teaching reading for advanced learners. The text can be varied as long as it fulfills the principles of CDA model by Wodak (2009). By using CDA perspective, students are asked to build their critical thinking to improve their reading ability. 


\section{REFERENCES}

Abdelhafez, H. A., \& Abdallah, M. M. S. (2015). Making it "authentic": Egyptian EFL student teachers' awareness and use of online authentic language materials and their learning motivation. Journal of Research in Curriculum, Instruction, and Educational Technology (JRCIET), (1).

Ali, S. (2011). Critical language awareness in pedagogic context. English Language Teaching, 4(4), 28-35. http://doi.org/10.5539/elt.v4n4p28

Amari, F. Z. (2015). The role of critical discourse analysis in EFL teaching/learning. Frontiers of Language and Teaching, 6, 87-93.

Brown, H. D. (2001). Principles and classroom practices. New York: Longman.

Coppens, X., Rico, M., \& Agudo, J. E. (2013). Using blogs: Authentic material and ranking quality for. The EUROCALL Review, 21(1), 20-34.

Ghazivakili, Z., Nia, R. N., Panahi, F., Karimi, M., Gholsorkhi, H., \& Ahmadi, Z. (2014). The role of critical thinking skills and learning styles of university students in their academic performance. Journal of Advances in Medical Education and Professionalism, 2(3). (Online), Retrieved from http://www.ncbi.nlm.nih.gov/pmc/articles/PMC4235550/

Gurses, M. O., \& Adiguzel, O. C. (2013). The effect of strategy instruction based on the cognitive academic language learning approach over reading comprehension and strategy use. Journal of Education and Learning, 2(2). http://doi.org/10.5539 hel.v2n2p55

Harmer, J. (2007). The practice of English language ( $4^{\text {th }}$ Ed.). New York: Longman.

Junining, E. (n.d.). Critical thinking stages in reading, 1-16. (Online), Retrieved from http:/fib.ub.ac.id/wrp-con/uploads/Critical-Thinking-Stages-inReading.pdf

Mandal, B. S. (2014). The "quit India" speeches by Mahatma Gandhi. (Online), Retrieved from http:/wwww.mkgandhi.org/speeches/speechMain.html.

Masduqi, H. (2014). EFL reading in Indonesian universities: Perspectives and. Journal of Teaching and Education, 3(3), 385-397.

Rahayu, E. Y. \& Februariyanti, H. (2015). Implementation of online reading assessments to encourage reading interests. English Language Teaching, 8(11), 197-206. http://doi.org/10.5539/elt.v8n11p197

Rahimi, A. (2010). Teaching reading with a critical attitude: Using critical discourse analysis (CDA) to raise EFL university students' critical language awareness (CLA). International Journal of Criminology and Sociological Theory, 3(2), 457-476.

Rodli, M. (2015). Applying PQ4R strategy for teaching reading. Indonesian EFL Journal: Journal of ELT, Linguistics, and Literature, 1(1), 31-41

Samadikhah, M., \& Shahrokhi, M. (2015). A critical discourse analysis of ELT materials in gender representation: A comparison of the summit and top 
notch. English Language Teaching, 8(1), 121-133. http://doi.org/10.5539/elt.v8n1p121

Sunggingwati, D. (2013). Teachers ' questioning in reading lessons: A case study in Indonesia. Electronic Journal of Foreign Language Teaching, 10(1), 80-95.

Thomas, C. (2014). Meeting EFL learners halfway by using locally relevant authentic materials. English Teaching Forum, (3).

Ubaidillah, M. F. (n.d.). Critical thinking skills in EFL learning: A glimpse overview on the theoretical framework.

Ullah, M., \& Fatema, S. (2013). Why some students are less motivated in reading classes at tertiary level in Bangladesh. English Language Teaching, 6(5), 129-140. http://doi.org/10.5539/elt.v6n5p129

Wodak, R. (2009). Discourse analysis: History, agenda, theory, and methodology. Methods for Critical Discourse Analysis, 1-33.

Zainuddin. (2015). The effect of cooperative integrated reading and composition technique on students ' reading descriptive text achievement. English Language Teaching, 8(5). http://doi.org/10.5539/elt.v8n5p11

\section{Author's Brief CV}

Elok Putri Nimasari is an English Lecturer of Engineering Faculty of the Muhammadiyah University of Ponorogo. She gained her master degree in Sebelas Maret University. She has been a presenter at several conferences such as the 1st TECHLIN UNESA, the 7th COTEFL UNMUH Purwokerto, the 1st ICTTE UNS Solo, TESOL Indonesia International Conference Lombok 2016, and the $63^{\text {rd }}$ TEFLIN. Her major study concerns on analyzing material and teaching development for ESP class. 